\title{
COMPETITIVE CONDITIONS IN THE TURKISH BANKING SYSTEMS
}

\section{DOI: 10.17261/Pressacademia.201519950}

Taner SEKMEN ${ }^{1}$, Omer AKKUS ${ }^{2}$, Ilyas SIKLAR ${ }^{3}$

1Eskişehir Osmangazi University. E-mail: tsekmen@ogu.edu.tr

${ }^{2}$ Anadolu University. E-mail: oakkus@anadolu.edu.tr

${ }^{3}$ Anadolu University. E-mail: isiklar@anadolu.edu.tr

\section{Keywords:}

Competition, Panzar-Rosse Model, Turkish Banking Sector, H-Statistic

JEL Classification:

\begin{abstract}
In this paper, we investigate competition in the Turkish banking sector over the period 2003- 2012. To understand the competitive conditions in the Turkish banking sector, we use the well-known Panzar-Rosse model based on a nonstructural estimation of the $\mathrm{H}$ statistic by employing the quarterly panel data set. The empirical evidence indicates that the Turkish banking sector operates under conditions of monopolistic competition. Therefore, although there have been growing structural changes in the Turkish banking sector since the 2000s, there has been no remarkable change in the market structure of the Turkish banking sector compared to previous studies, and it can still be characterized by monopolistic competition.
\end{abstract}

\section{INTRODUCTION}

Turkey's banking sector went through significant structural changes following the 20002001 economic crisis. In the aftermath of the crisis, a rise in the interest rate, depreciation of the Turkish Lira and a depression in economic activity adversely influenced the profitability of banks in Turkey. Corresponding with financial and functional revival efforts, the number of banks, branches of banks and the number of employees were reduced as a consequence of the Banking Sector Reconstruction Program. The equity of private banks was reinforced. Merger and acquisition activities were encouraged. The economic crisis highlighted the crucial role that banks have in the Turkish economy.

The banks have a vital role due to different aspects of the economy. For instance, economic developments in the banking system accelerate the liberalization of capital flow, expanding the common market within countries. Further, the improvements occurring in the banking sector stimulate the service innovation in financial markets and the internationalization of banking activities. On the other hand, the competitive pressure occurring in the banking industry and the deterioration of the banks as a financial intermediary alter the banking behavior and market structures. The changing market structure for banks plays a substantial role in capital accumulation and economic prosperity. 
There are some general reasons why the market conditions in the banking industry deserve particular attention. For instance, financial austerity and financial stability may be influenced in some ways by the degree of competition and concentration (Yeyati and Micco, 2003). From a theoretical point of view, competition may have a detrimental impact on economic stability if it drops the bank charter value. Therefore, the incentives for cautious risk-taking behavior exhibit a tendency to decrease. According to this view, the promise of extraordinary profits occurring in the course of time with the presence of market power decreases the agency problem of limited banks. More aggressive risk taking could lead to stricken competition (Cerasi and Daltung, 2000). From another point of view, a more concentrated system is more likely to demonstrate "too big to fail", a problem whereby large banks increase their risk exposure expecting the reluctance of the regulator to let the bank fail in the event of insolvency problems (Hughes and Mester, 1998).

According to Lerner (1934), the theory maintains that banking competition could be a direct result of the markup of price over the marginal cost. The theory suggests a good way to measure banking competition. However, in practice, it is difficult to measure the degree of competition due to the absence of detailed data on cost and the prices of bank products. The literature has created several measurement techniques to evaluate competitive conditions in the banking industry. The structural and non-structural approaches can be viewed to be the two main measurements methods. The structural methods are based on the Structural Conduct Performance (SCP) paradigm, which was developed by Mason (1939) and Bain (1951) and estimates that more concentrated markets are more collusive. Competition is a proxy for measures of bank concentration. However, the empirical banking literature has indicated that concentration is broadly a weak measurement of competition; see, e.g., (Shaffer, 1989, 1993, 2004), (Shaffer and Disalvo, 1994), (Claessens and Laeven, 2004). The Panzar-Rosse approach and BresnahanLau method are two non-structural methods of evaluating competition in the style of the New Empirical Industrial Organization (NEIO) literature. Both methods are based on the derivation of profit-maximizing equilibrium conditions, which is their major advantage over more empirical approaches. Their test statistics are systematically related to one another and to alternative measurements of competition such as the Lerner index (Lerner, 1934).

Our paper focuses on the Panzar-Rosse $(P-R)$ revenue test. This approach has been widely used in empirical banking studies. The Panzar-Rosse approach estimates a reduced-form equation relating gross revenue to a vector of input price and other control variables. The measure of competition, usually called the "H statistics", is attained as the sum of the elasticities of gross revenue with respect to input price. The aim of this paper is to assess the current market structure of the banking industry and the degree of competition in Turkey over the period 2003-2012 using the Panzar-Rosse H-statistic. 
The rest of paper is organized as follows: the second section outlines the evolution of the Turkish banking sector and discusses the crucial properties of the Turkish banking sector regulations; the third section presents an overview of the empirical literature on banking competition; the fourth section presents the Panzar-Rosse Analytical Framework and describes the econometric model and data to be used; the fifth section addresses the estimation results of the empirical analysis; and the sixth section summarizes the findings of the research.

\section{OVERVIEW OF THE TURKISH BANKING SECTOR}

During the 1980's, the Turkish economical system witnessed many structural changes such as regulations in financial liberalization and the banking system. In this context, the interest rate ceiling system collapsed, the exchange rate was left to fluctuation, liberalization was ensured and the Interbank Money Market was established to regulate liquidity conditions in the banking system. Additionally, the Capital Markets Board and the Istanbul Stock Exchange was established to increase the competitiveness and efficiency in the financial markets. The transition to a fully convertible form of the Turkish Lira was achieved only after capital account liberalization in 1989. New entries into the banking system were facilitated, and the operations of foreign banks were encouraged to increase the competitiveness and efficiency in the banking system. In addition, Turkish banks started operating abroad by purchasing banks or launching branches and representative offices. The fact that exchange rate regulations have become increasingly liberal has dramatically increased the exchange rate transactions of banks.

Despite positive improvements during the 1980's, many structural problems began emerging. Initially, government banks in the banking system had a significant presence. The distortions resulting from the duty losses of these banks marked the 1990s. Moreover, new bank licensing resulting in the market entry of new banks was made on the basis of political criteria that created a disruptive effect on efficiency and development in the banking sector (Alper and Öniş, 2004: 25-55). In addition, supervision and regulation in the banking sector were weak, and they were directly involved in the regulation process (Alper and Öniş, 2004: 25-55). During this period, because of the absence of a properly regulated and closely audited banking system, the entity of foreign banks in the sector has been at a negligible level.

During the 1990s, private banks witnessed significant instabilities. First, in the beginning of the 1990s, the loan policy of private banks was swapped from external debt sources to internal debt instruments. Because government securities income was high, banks began reducing traditional banking activities such as giving credit to the real sector and invested more in these government securities, which were more risk free. This situation, at the same time, motivated new entries into the banking sector. In addition, new banks have been established by industrial groups for the purpose of using collected deposits as an asset to finance their own companies. In consequence, the increase in the number of banks continued in the 1990s as well. In the free capital movement environment, many banks, especially private banks, tried to benefit from arbitrage opportunities. Banks were moving into debt with foreign currency, but they were holding government securities in the TL unit. Consequently, they had a weak position that made them extremely vulnerable to speculative attacks. 
In addition, insufficient capital amount, maturity mismatch, high deficit level, inadequate risk management experience and mismanagement contributed to structural problems in the banking sector (Akyüz and Boratav, 2002; Sayılgan and Yıldırım, 2009).

All these negative conditions and characteristics have placed the banking system in a vulnerable position with regard to macroeconomic crises. Financial crises in 2000-2001 made the banking system even worse, and it was already weak.

In the years 1997-2002, because they did not fulfill their liabilities, 21 banks were transferred to the Saving Deposits Insurance Fund (SDIF). After the 2000-2001 financial crisis, with the start of the transition to a strong economic program, Turkey's economy experienced a remarkable recovery. A vital part of this program was the restructuring of the banking system, which created positive outcomes. Restructuring governmental banks in financial and operational terms, the consolidation of private banks, and developments in the field of regulation and supervision contributed to the improvement in the banking system. The banks bought by SDIF were either sold or joined, or liquidity conditions were improved. As a result, the number of the deposit banks was reduced. Moreover, positive macroeconomic conditions and the recapitalization and restructuring process in the banking sector, which contributed to attracting foreign investors' attention in the consolidation process, enhanced direct capital flow. In the 1990s, banks that were the main source of financing government deficit finally returned to the traditional role of being an intermediary to finance households and the financial sector.

Table-1 illustrates the changes of the number of banks in the Turkish banking system in the years 2000-2014. In addition, it demonstrates the composition of the operation fields of banks (i.e., deposit vs. development and investment) and the total number of assets. As mentioned previously, during the 1990s, because of the convenience of founding a bank and the attractiveness of the banking business, the number of banks has been exponentially increasing. In the years 1990 and 1995, the number of banks was 66 and 68, respectively, but in the year 2000, this number reached 79 . As indicated in the table, because many banks went bankrupt and transferred to SDIF, during the financial crisis in 2000-2001, the number of banks started to decrease. After 2001, the number continued to diminish, and since 2005, it has stabilized. The main reason for the decrease after 2002 is the restructuring of the banking system and the consolidation process of the Turkish banks especially with regard to foreign banks, which resulted from positive macroeconomic conditions. 
Table 1: Number of Banks in the Turkish Banking System 2000-2014

\begin{tabular}{|l|c|c|c|c|c|c|c|c|c|c|c|c|c|c|c|}
\hline & 2000 & 01 & 02 & 03 & 04 & 05 & 06 & 07 & 08 & 09 & 10 & 11 & 12 & 13 & 14 \\
\hline Deposit Banks & 61 & 46 & 40 & 36 & 35 & 34 & 33 & 33 & 32 & 32 & 32 & 31 & 32 & 32 & 32 \\
\hline State-Owned & 4 & 3 & 3 & 3 & 3 & 3 & 3 & 3 & 3 & 3 & 3 & 3 & 3 & 3 & 3 \\
\hline Private & 28 & 22 & 20 & 18 & 18 & 17 & 14 & 11 & 11 & 11 & 11 & 11 & 12 & 10 & 10 \\
\hline SDIF & 11 & 6 & 2 & 2 & 1 & 1 & 1 & 1 & 1 & 1 & 1 & 1 & 1 & 2 & 1 \\
\hline Foreign & 18 & 15 & 13 & 13 & 13 & 13 & 15 & 18 & 17 & 17 & 17 & 16 & 16 & 17 & 18 \\
\hline $\begin{array}{l}\text { Development } \\
\text { and } \\
\text { Investment } \\
\text { Banks }\end{array}$ & 18 & 15 & 14 & 14 & 13 & 13 & 13 & 13 & 13 & 13 & 13 & 13 & 13 & 13 & 13 \\
\hline State-Owned & 3 & 3 & 3 & 3 & 3 & 3 & 3 & 3 & 3 & 3 & 3 & 3 & 3 & 3 & 3 \\
\hline Private & 12 & 9 & 8 & 8 & 8 & 8 & 6 & 6 & 6 & 6 & 6 & 6 & 6 & 7 & 7 \\
\hline Foreign & 3 & 3 & 3 & 3 & 2 & 2 & 4 & 4 & 4 & 4 & 4 & 4 & 4 & 3 & 3 \\
\hline Total & 79 & 61 & 54 & 50 & 48 & 47 & 46 & 46 & 45 & 45 & 45 & 44 & 45 & 45 & 45 \\
\hline
\end{tabular}

Figure 1 presents the change in ownership of the banks. Since 2000, the number of domestic banks with private ownership has been decreasing. The decrease in the beginning of the 2000s was substantially based on the transfer of the banks to SDIF. However, this situation is a result of the consolidation process with foreign banks in recent years.

Moreover, owing to positive macroeconomic conditions and developments in the banking sector after the crisis, the market share of foreign banks increased. Since the year 2000, the number and proportion of governmental banks have comparatively stabilized.

Figure 1: The Ownership Composition of Banks in Turkey: 2000-2014

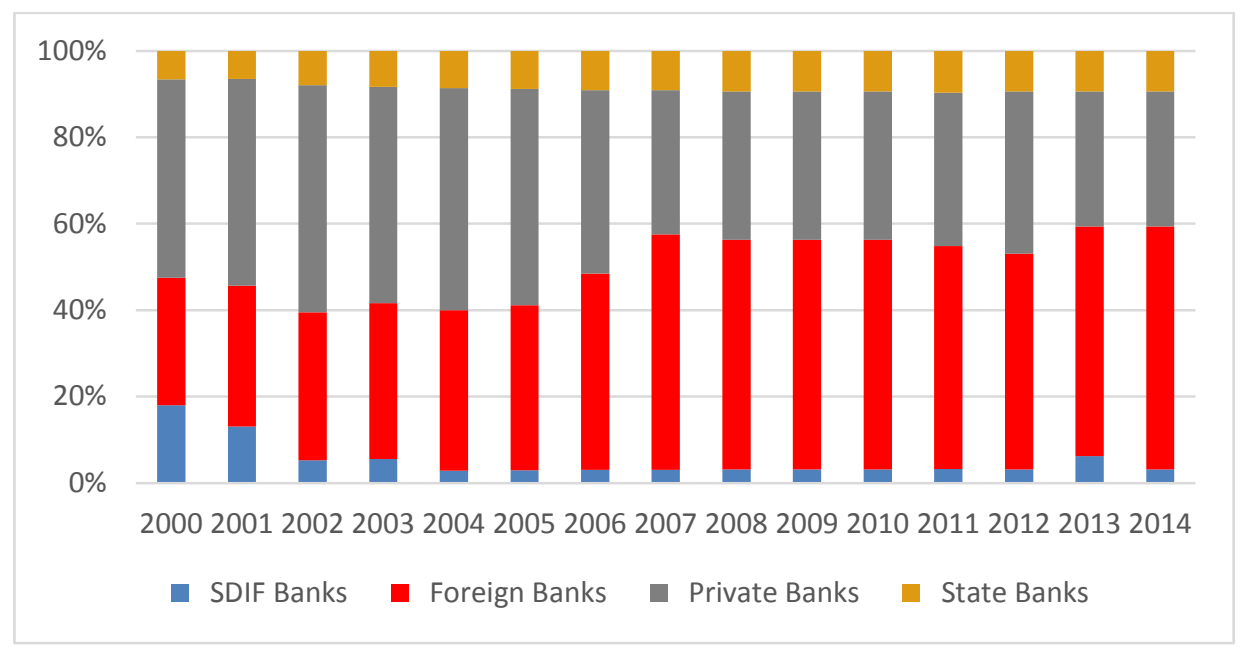

Figure 2 indicates the composition of banks according to the operational range. In general, the portion of deposit banks is greater than the portion of development banks. The proportion of deposit banks in the Turkish banking system is approximately $75 \%$. However, since the year 2000, the proportion of deposit banks has been constantly decreasing, and it was, to some degree, fixed during 2000-2014. 
Figure 2: Composition of Banks According to Field of Operation: 2000-2014

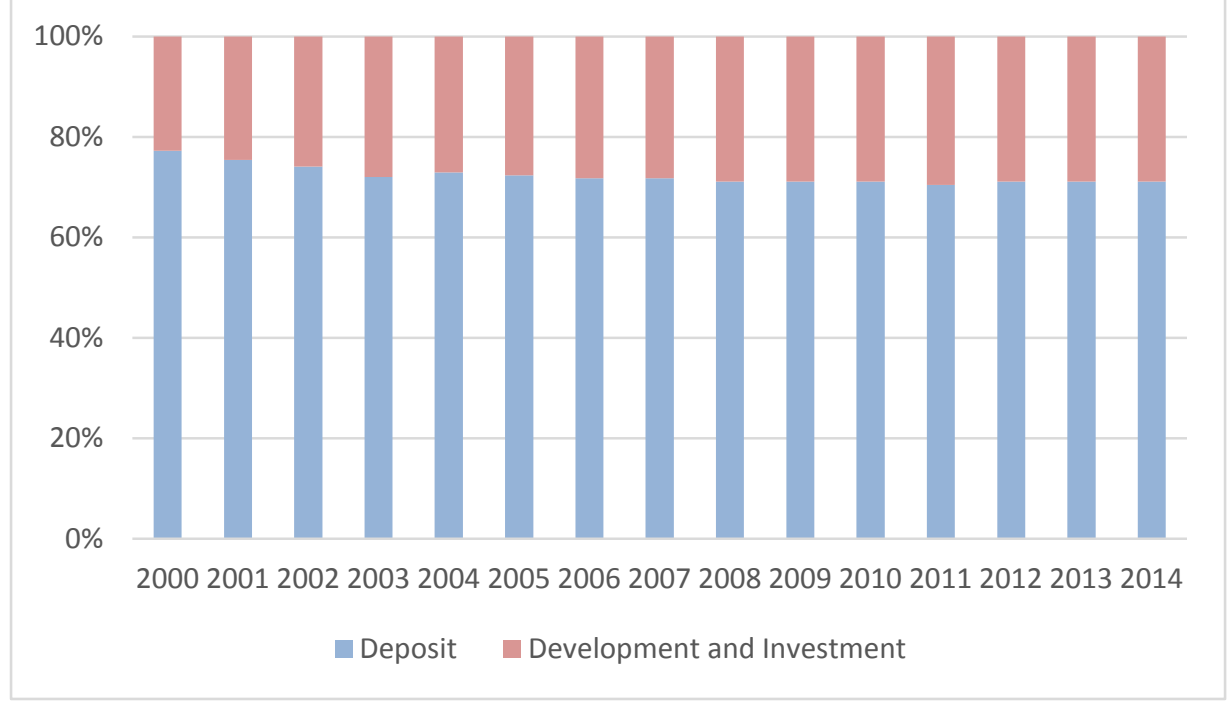

Nevertheless, the competitive conditions of the banking system in Turkey have never been satisfactory, and a modern system that is flexible and market-oriented is needed. However, with liberalization and deregulation, an apparent improvement was seen in competitiveness. Despite the reduction in market concentration due to the deregulation during the period before the crisis, reduction in the number of banks has considerably increased since the crisis, in addition to bank consolidation and the formation of mega banks. Along with these changes, there are growing concerns regarding market power in Turkish banking sector

\section{LITERATURE REVIEW}

Although there are comprehensive studies of banking competition in the literature, the Panzar-Rosse methodology is used by a very limited number of studies. Shaffer (1982) examined the competitive conditions in New York using a cross-section series. According to Shaffer's study, the banks were neither as monopolistic nor as perfectly competitive in the long run. Nathan and Neave (1989) applied the cross-section series for Canadian Banks for the 1982-1984 period. Their estimation results indicated that Canadian Banks had monopolistic competition structures. Bikker and Haaf (2000) found monopolistic competition in the banking industry using 23 industrialized countries for the 1988-1998 period. De Bandt and Davis (2000) examined four countries, and their estimation results suggested that competition was stronger for banks operating more in international markets and weaker for banks operating in local markets. Bikker and Haaf (2002) made an assessment of the banking industries in 17 European countries and 6 non-European countries. Their study indicated that all the countries had nearly monopolistic competition. The large banks were much more competitive than the small banks, and the environment in the international market was much more competitive than in the local market. 
Claessens and Laeven (2003) used bank-level data and examined the competitive conditions of the banking systems in 50 countries. They argued that monopolistic competition is the best description of the degree of competition. Bikker and Groeneveld (2000) examined the competitive structure of the European Union (EU) banking industry as a whole and also for individual EU countries for the 1989-1996 period. Their study indicates that nearly all countries had a monopolistic competition structure, although competition in Ireland and Denmark was relatively low. Weill (2004) investigated the relationship between competition and efficiency in banking with a sample of $12 \mathrm{EU}$ countries during the period 1994-1999. This study supported the idea that there is a negative relationship between competition and efficiency in banking. Yildirim and Philippatos (2002) examined the competitive conditions in the banking industries of fourteen Central and Eastern European transition economies for the period 1993-2000. The results suggested that the banking industries in these countries, except for those of Macedonia and Slovakia, had a monopolistic competition structure under the period. Moreover, the large banks in transition countries were operating in a relatively more competitive environment, whereas the competition was lower in local markets compared to national and international markets. Drakos and Konstantinou (2003) focused on the competitive conditions in the banking industry of Central and Eastern European countries for the period 1992-2000. The study results suggested that banking in transition economies as a whole was consistent with a monopolistically competitive market structure.

Gelos and Roldos (2004) evaluated the competitive conditions of a sample of Latin America and Central and Eastern European countries for the period 1994-1999. The results indicated that the banking industry had monopolistic competition for allcountries except for Argentina and Hungary. Murjan and Ruza (2002) assessed some Middle Eastern countries from 1993 to 1997, and the results indicated that the market had monopolistic competition. It was found that oil-producing countries were less competitive than non-oilproducing countries. Some recent empirical studies about the issue can be listed as follows: Casu and Girardone (2009) for European countries, Delis and Tsionas (2009) for European countries, Maudos and Fernandez de Guevara (2007) and Andries and Capraru (2012a) for European countries, Koetter et al. (2012) for the U.S.A., Al-Muharrami and Matthews (2009) for the Arab Gulf, Fu and Heffernan (2009) for China, and Andries and Capraru (2013) for 27 European Union Countries. There are not many studies determining competitive conditions using the Panzar and Rosse model in the Turkish banking industry. Aydın (1996), for the period 1991-1994, and Emek (2005), for the period 1990-2003, obtained results indicating that the market was monopolistic according to their estimation, whereas Kasman (2001). for the period 1983-1996, Gelos and Roldos (2004), for the period 1994-2000, Classens and Leaven (2004), for the period 1994-2001, Günalp and Celik (2006), for the period 1990-2000, Aysan and et al. (2007), for the period 20012005, and Celik and Kaplan (2010) found a monopolistically competitive market for the Turkish banking sector. 


\section{DATA AND METHODOLOGY}

To measure competition in the banking sector, we adopt the Panzar and Rosse (1987) methodology, which aims to estimate the degree of competition. The Panzar and Rosse model provides the $\mathrm{H}$-statistic as a measure of competition. The $\mathrm{H}$-statistic is the sum of the elasticities of the reduced form revenue function with respect to factor prices. The reduced form revenue function can be described as follows:

$$
R_{i t}=f\left(w_{i t}, Z_{i t}, Y_{i t}, \varepsilon_{t}\right)
$$

where $w_{i t}$ is the vector of factor prices, $Z_{i t}$ is the variables shifting the cost function, $Y_{i t}$ is the variables shifting the demand function and $\varepsilon_{t}$ is the error term. $\partial R_{i t} / \partial w_{i t k}$ illustrate the derivative of total revenue with respect to the price of the $k$ th input, and the $\mathrm{H}$ statistic can be written as follows ${ }^{1}$ :

$$
H=\sum_{k}\left[\frac{\partial R_{i t}}{\partial w_{i t}} \frac{w_{i t}}{R_{i t}}\right]
$$

To test the market equilibrium, we use the following specification of the reduced form of the revenue equation for a panel data set:

$$
\begin{gathered}
\ln T R_{i t}=\alpha+\beta_{1} \ln W_{L, i t}+\beta_{2} \ln W_{F, i t}+\beta_{3} \ln W_{C, i t}+\gamma \ln T A_{i t}+\delta \ln N P L_{i t} \\
+\theta \ln N L_{i t}+\varepsilon_{i t}
\end{gathered}
$$

where it denotes bank $i$ at time $t, T R$ is the ratio of total revenue (or gross interest revenue) to total assets, $W_{L}$ is the unit price of labor (the ratio of personnel expenses to total assets), $W_{F}$ is the unit price of fund (the ratio of interest expenses to total deposits), and $W_{C}$ is the unit price of capital (the ratio of other operating and administrative expenses to total assets). In addition, a set of variables composed of bank-specific factors is included in the model. These variables include $T A$, which is the total assets to control the potential size effect of banks, NPL is the ratio of non-performing loans to total assets, $N L$ is the ratio of net loans to total assets and $\varepsilon$ is the error term. We also use two additional macroeconomic control variables, the nominal treasury bill rate (INT) and the inflation rate $(I N F)$. It is clear that all of the variables are in natural logarithm to represent the elasticity of coefficients.

The $\mathrm{H}$-statistic is the sum of the elasticities of the total revenue with respect to the input prices, $H=\beta_{1}+\beta_{2}+\beta_{3}$. The Panzar-Rosse (1987) $\mathrm{H}$-statistic was basically designed to determine the market structure. The market structure is characterized by a monopoly, a perfectly colluding oligopoly or a homogeneous conjectural variations oligopoly when the $\mathrm{H}$-statistic is negative or equal to zero $(H \leq 0)$. An increase in the input prices raises marginal costs and reduces equilibrium output as well as total revenue under these market structures. Under perfect competition, because an increase in input prices increases both marginal and average costs without shifting the optimal output decision of any individual bank, the value of the $\mathrm{H}$-statistic is equal to unity $(H=1)$.

\footnotetext{
${ }^{1}$ For a more comprehensive explanation of the H-statistic, see Panzar and Rosse (1987)
} 
If the H-statistic is between zero and unity, the market structure is considered a monopolistic competition $(0<H<1)$. In a monopolistic competition market, an increase in revenue will be less than a proportional increase in input prices.

In the empirical applications, the monopoly model is noted by the rejection of the $H \leq 0$ hypothesis. The rejection of hypothesis $H \leq 1$ does not accompany the above three models, and the rejection of the $H \leq 0$ and $H=1$ hypotheses together indicate that only the monopolistic competition model is coherent with the data (Panzar and Rosse 1987). Finally, a crucial assumption of the Panzar-Rosse model is that the banking markets are in long-run equilibrium. To control the long-run equilibrium assumption, Shaffer (1982) suggests a test based on the H-statistic (or E-Statistic). The competitive capital markets will equalize the risk-adjusted rate of return across banks in equilibrium, and hence, the input prices should not be significantly correlated to the rate of return. The long-run equilibrium test is performed by running the same regression but using the pre-tax return on assets ROA as the dependent variable instead of total revenue.

$$
\begin{aligned}
& \ln R O A_{i t}=\alpha+\beta_{1} \ln W_{L, i t}+\beta_{2} \ln W_{F, i t}+\beta_{3} \ln W_{C, i t}+\gamma \ln T A_{i t}+\delta \ln N P L_{i t} \\
& +\theta \ln N L_{i t}+\varepsilon_{i t}
\end{aligned}
$$

$E=\sum_{i=1}^{3} \beta_{i}$ is the sum of the elasticities of the reduced form revenue function with respect to factor prices. $E=0$ indicates that the markets are in equilibrium. In empirical applications, the dependent variable is usually $\ln (1+R O A)$ instead of $\ln R O A$ because $R O A$ may take small negative values.

We employ quarterly balanced panel data covering the period 2003Q1 to 2012Q4 for 10 of the biggest banks in Turkey. Bank-level data for all banks are gathered from The Banks Association of Turkey, whereas the nominal treasury bill rate (INT) and the inflation rate $(I N F)$ are obtained from the Central Bank of the Republic of Turkey Database (CBRT). The sample, composed of the biggest 10 banks listed by The Banks Association of Turkey in the banking system according to total assets, represents an approximately $87 \%$ share in the total assets for the period under this study. Table 1 indicates the summary statistics of the variables in the sample period. 
Table 1: Descriptive Statistics

\begin{tabular}{llllll}
\hline Variable & Obs. & Mean & Std. Dev. & Min. & Max. \\
\hline ROA & 400 & .006951 & .0070998 & -.1078472 & .0366739 \\
ROA1 & 400 & 1.006951 & .0070998 & .8921528 & 1.036674 \\
\hline IR & 400 & 1458.526 & 943.9017 & 73.56 & 4892.154 \\
R & 400 & .0296864 & .008413 & .009521 & .0739355 \\
TR & 400 & 2372.98 & 1507.712 & 33.311 & 6468.84 \\
TRO & 400 & .0485998 & .0142979 & .0005227 & .1847103 \\
\hline W $_{\text {L }}$ & 400 & .0036213 & .0012267 & .0016282 & .0079643 \\
WF $_{\text {F }}$ & 400 & .0268607 & .0098464 & .0045063 & .083586 \\
W & 400 & .0060745 & .0051477 & .0010177 & .0889986 \\
\hline TA & 400 & 55285.48 & 42784.17 & 2273.011 & 175444.5 \\
NPL & 400 & .0607729 & .0922607 & .0086166 & .8970762 \\
NL & 400 & .4595439 & .1499711 & .0070735 & .7058426 \\
INF & 400 & .096752 & .0447968 & .0435056 & .2718 \\
INT & 400 & .1676325 & .0820434 & .0792 & .456 \\
\hline
\end{tabular}

Table 2: Correlation Matrix Between Dependent Variables

\begin{tabular}{lllllllll}
\hline & $\mathrm{W}_{\mathrm{L}}$ & $\mathrm{W}_{\mathrm{F}}$ & $\mathrm{W}_{\mathrm{C}}$ & $\mathrm{TA}$ & $\mathrm{NPL}$ & $\mathrm{NL}$ & INF & INT \\
\hline $\mathrm{W}_{\mathrm{L}}$ & 1.000 & & & & & & & \\
$\mathrm{~W}_{\mathrm{F}}$ & 0.263 & 1.000 & & & & & & \\
$\mathrm{~W}_{\mathrm{C}}$ & 0.337 & 0.145 & 1.000 & & & & & \\
$\mathrm{TA}$ & -0.713 & -0.462 & -0.340 & 1.000 & & & & \\
$\mathrm{NPL}$ & 0.076 & 0.661 & -0.000 & -0.215 & 1.000 & & & \\
$\mathrm{NL}$ & 0.125 & -0.535 & 0.036 & 0.099 & -0.575 & 1.000 & & \\
INF & 0.219 & 0.627 & 0.166 & -0.298 & 0.414 & -0.400 & 1.000 & \\
INT & 0.338 & 0.778 & 0.231 & -0.521 & 0.441 & -0.568 & 0.872 & 1.0 \\
\hline
\end{tabular}

\section{RESULTS}

In Table 3, we report the results of the Panzar-Rosse model for two different dependent variables, total revenue TR and interest revenue IR. The regression models are estimated using the random effects estimator. The sample includes the 10 biggest banks in Turkey for the period 2003-2012. Selecting the 10 biggest banks reduces significantly the unobserved heterogeneity; thus, the random effects estimator is more coherent with data that is quite homogeneous. Moreover, our choice of the random effects versus OLS and the fixed effects estimators is supported by the implementation of the Breusch-Pagan LM test and the Hausman test, respectively. The statistical tests confirm that the model fits the data very well. The Wald Chi2 test is significant at the $1 \%$ level in all models. To control heteroscedasticity, the robust standard errors are applied.

Column 2 and 3 indicate the regression results for total revenue TR as the dependent variable, whereas column 4 and 5 indicate the results for interest revenue IR. 
In both column 2 and 3 , the sign of coefficients for all input prices $\mathrm{W}_{\mathrm{L}}, \mathrm{W}_{\mathrm{F}}$ and $\mathrm{W}_{\mathrm{C}}$ are always positive, but only the coefficient of the price of the fund $W_{F}$ is statistically significant and is bigger than the other two inputs in all regressions. Although the coefficients and statistics for the prices labor $\mathrm{W}_{\mathrm{L}}$ are quite close to each other in Models 1 and 2 , the coefficient of $W_{L}$ is statistically significant at only the $10 \%$ level in Model 2 . Column 4 and 5 report the regression results for the interest revenue IR, and the results are similar to those of the first two models. However, the coefficients for the price of capital $\mathrm{W}_{\mathrm{C}}$ are statistically significant for all regressions, and the sign of coefficients is negative in Models 3 and 4 . The three bank-specific factor variables included in the regressions are the total assets TA to control the potential size effect of banks, NPL as the ratio of non-performing loans to total assets, and NL as the ratio of net loans to total assets. The variable TA has a positive sign and is highly significant in all regressions. Thus, it is clear that there is a potential size effect. The other independent variable, the ratio of non-performing loans to total assets NPL, has statistically insignificant coefficients for all regressions, and the coefficients have a positive sign for Model 2. Conversely, the ratio of net loans to total assets NL has a statistically significant and positive effect on total revenue but is insignificant on interest revenue. To control the macroeconomic environment, two additional variables, nominal treasury bill rate INT and inflation rate INF, are included in the regressions. The macroeconomic control variables display unstable results. Although the inflation rate INF has a negative effect on both the total revenue and interest revenue, it is statistically significant at only the $10 \%$ level for interest revenue. Finally, the coefficient of the nominal treasury bill rate INT is not statistically significant and has a different sign for the two dependent variables. 
Table 3: Panel Regression Results of Competitive Conditions in the Turkish Banking Market

\begin{tabular}{lcccc}
\hline Variables & Model(1) & Model(2) & Model(3) & Model(4) \\
& TR & TR & IR & IR \\
\hline $\ln \mathrm{W}_{\mathrm{L}}$ & 0.105 & $0.106^{*}$ & $0.122^{*}$ & 0.135 \\
& {$[0.065]$} & {$[0.059]$} & {$[0.073]$} & {$[0.084]$} \\
$\ln \mathrm{F}_{\mathrm{F}}$ & $0.238^{* *}$ & $0.257^{* *}$ & $0.528^{* * *}$ & $0.490^{* * *}$ \\
& {$[0.103]$} & {$[0.103]$} & {$[0.049]$} & {$[0.077]$} \\
$\ln \mathrm{W}_{\mathrm{C}}$ & 0.063 & 0.063 & -0.022 & -0.033 \\
& {$[0.051]$} & {$[0.042]$} & {$[0.038]$} & {$[0.041]$} \\
$\ln \mathrm{TA}$ & $0.935^{* * *}$ & $0.926^{* * *}$ & $0.966^{* * *}$ & $0.976^{* * *}$ \\
& {$[0.028]$} & {$[0.043]$} & {$[0.024]$} & {$[0.021]$} \\
InNPL & 0.002 & -0.003 & 0.018 & 0.022 \\
& {$[0.034]$} & {$[0.036]$} & {$[0.030]$} & {$[0.027]$} \\
InNL & $-0.160^{* *}$ & $-0.166^{*}$ & -0.055 & -0.043 \\
& {$[0.074]$} & {$[0.086]$} & {$[0.043]$} & {$[0.039]$} \\
lnINF & -0.064 & & $-0.060^{*}$ & \\
& {$[0.045]$} & & {$[0.036]$} & \\
lnINT & & -0.067 & & 0.017 \\
& & {$[0.125]$} & & {$[0.077]$} \\
Constant & $-0.863^{* *}$ & -0.687 & $-0.804^{* * *}$ & $-0.832^{* *}$ \\
& {$[0.407]$} & {$[0.497]$} & {$[0.235]$} & {$[0.405]$} \\
\hline
\end{tabular}

Note: ${ }^{*}$ Denotes significance at the $10 \%$ level, and ${ }^{* *}$ at the $5 \%$ level and ${ }^{* * *}$ at the $1 \%$ level. The robust standard errors of coefficients are in brackets. The probability values are presented also in brackets for Hausman Test, Breusch-Pagan LM and Wald Test

The findings of the $\mathrm{H}$-statistic are also shown in Table 3. The $\mathrm{H}$-statistics lie between 0 and 1 for all specifications of the dependent and independent variable. In our first specifications (for total revenue), the $\mathrm{H}$-statistics are smaller than the other specifications of the dependent variable (for interest revenue). For the period 2003-2012, the average value of the $\mathrm{H}$-statistic is 0.513 and is found to be statistically significant in all different specifications. The Wald tests indicate that $\mathrm{H}$-statistics differ significantly from both zero and unity, and thus, we clearly reject the hypotheses of monopoly $(\mathrm{H} \leq 0)$ and perfect competition $(\mathrm{H}=1)$ for the Turkish banking market during the period under study. Therefore, the results indicate that the Turkish banking market can be characterized as having monopolistic competition. Finally, Table 4 displays the long-run equilibrium results derived from running the same regressions for the pre-tax return on assets InROA and $\ln (1+\mathrm{ROA})$ as the dependent variable instead of $\ln \mathrm{TR}$ and $\ln I R$. 
We test the null hypothesis $E=0$ using the Wald test for the long-run equilibrium conditions, and the results of the Wald test indicate that the null hypothesis cannot be rejected in all regressions. Therefore, the long-run equilibrium condition is supported for the Turkish banking market during the period 2003-2012.

Table 4: Equilibrium Test for the Turkish Banking Market

\begin{tabular}{|c|c|c|c|c|}
\hline Variables & $\begin{array}{l}\text { Model(1) } \\
\text { ROA }\end{array}$ & $\begin{array}{l}\text { Model(2) } \\
\text { ROA }\end{array}$ & $\begin{array}{c}\text { Model(3) } \\
1+\mathrm{ROA}\end{array}$ & $\begin{array}{c}\text { Model(4) } \\
1+\mathrm{ROA}\end{array}$ \\
\hline $\ln W_{L}$ & $\begin{array}{c}-0.368^{* * *} \\
{[0.135]}\end{array}$ & $\begin{array}{c}-0.339 * * \\
{[0.156]}\end{array}$ & $\begin{array}{c}-0.001 \\
{[0.003]}\end{array}$ & $\begin{array}{l}-0.001 \\
{[0.003]}\end{array}$ \\
\hline $\ln W_{F}$ & $\begin{array}{l}-0.210^{*} \\
{[0.118]}\end{array}$ & $\begin{array}{l}-0.083 \\
{[0.235]}\end{array}$ & $\begin{array}{l}-0.000 \\
{[0.001]}\end{array}$ & $\begin{array}{l}-0.003 \\
{[0.002]}\end{array}$ \\
\hline $\ln W_{C}$ & $\begin{array}{c}0.062 \\
{[0.123]}\end{array}$ & $\begin{array}{c}0.066 \\
{[0.137]}\end{array}$ & $\begin{array}{l}-0.006 \\
{[0.006]}\end{array}$ & $\begin{array}{l}-0.006 \\
{[0.006]}\end{array}$ \\
\hline $\operatorname{lnTA}$ & $\begin{array}{c}-0.208^{* * *} \\
{[0.062]}\end{array}$ & $\begin{array}{c}-0.284 * * * \\
{[0.079]}\end{array}$ & $\begin{array}{c}-0.002^{* *} \\
{[0.001]}\end{array}$ & $\begin{array}{c}-0.001 \\
{[0.001]}\end{array}$ \\
\hline $\ln N P L$ & $\begin{array}{c}-0.175^{* * *} \\
{[0.068]}\end{array}$ & $\begin{array}{c}-0.204^{* *} \\
{[0.092]}\end{array}$ & $\begin{array}{l}-0.001 \\
{[0.001]}\end{array}$ & $\begin{array}{c}-0.000 \\
{[0.001]}\end{array}$ \\
\hline $\ln N L$ & $\begin{array}{c}-0.422^{* * *} \\
{[0.128]}\end{array}$ & $\begin{array}{c}-0.448 * * * \\
{[0.164]}\end{array}$ & $\begin{array}{l}-0.001 \\
{[0.003]}\end{array}$ & $\begin{array}{c}0.000 \\
{[0.003]}\end{array}$ \\
\hline $\operatorname{lnINF}$ & $\begin{array}{l}-0.237^{*} \\
{[0.140]}\end{array}$ & & $\begin{array}{c}0.002 \\
{[0.002]}\end{array}$ & \\
\hline $\operatorname{lnINT}$ & & $\begin{array}{l}-0.353 \\
{[0.326]}\end{array}$ & & $\begin{array}{c}0.004 \\
{[0.003]}\end{array}$ \\
\hline Constant & $\begin{array}{c}-6.894^{* * *} \\
{[0.632]}\end{array}$ & $\begin{array}{c}-5.654 * * * \\
{[1.318]}\end{array}$ & $\begin{array}{l}-0.012 \\
{[0.010]}\end{array}$ & $\begin{array}{c}-0.021 \\
{[0.015]}\end{array}$ \\
\hline Observations & 394 & 394 & 400 & 400 \\
\hline Number of Bank & 10 & 10 & 10 & 10 \\
\hline Hausman Test & $\begin{array}{c}7.76 \\
(0.354)\end{array}$ & $\begin{array}{c}16.45 \\
(0.021)\end{array}$ & $\begin{array}{c}6.42 \\
(0.491)\end{array}$ & $\begin{array}{c}13.16 \\
(0.068)\end{array}$ \\
\hline Breusch-Pagan LM & $\begin{array}{c}67.14 \\
(0.000) \\
\end{array}$ & $\begin{array}{c}65.25 \\
(0.000) \\
\end{array}$ & $\begin{array}{c}11.34 \\
(0.000) \\
\end{array}$ & $\begin{array}{c}10.44 \\
(0.001)\end{array}$ \\
\hline E-Statistic & -0.516 & -0.356 & -0.007 & -0.010 \\
\hline $\begin{array}{l}\text { Wald Test (Chi2) for } \mathrm{H}=0 \\
\mathrm{P} \text { - value }\end{array}$ & $\begin{array}{c}1.97 \\
(0.160)\end{array}$ & $\begin{array}{c}0.84 \\
(0.360)\end{array}$ & $\begin{array}{c}0.37 \\
(0.540)\end{array}$ & $\begin{array}{c}0.00 \\
(0.966)\end{array}$ \\
\hline
\end{tabular}

Note: $*$ Denotes significance at the $10 \%$ level, and ${ }^{* *}$ at the $5 \%$ level and ${ }^{* * *}$ at the $1 \%$ level. The robust standard errors of coefficients are in brackets. The probability values are presented also in brackets for Hausman Test, Breusch-Pagan LM and Wald Test

\section{CONCLUSION}

Since the financial crisis of 2000-2001, the Turkish banking industry has witnessed dramatic structural changes. First, 21 banks were transferred to the SDIF. Although the ratio of privately owned domestic banks has continuously declined, the share of foreign banks has been increasing since the 2000s. Moreover, the total number of deposit banks decreased from 61 to 32 between 2000 and 2012; in addition, the mega banks were created. The ongoing changes in the Turkish banking sector may affect the market structure and the competitive conditions by increasing the market concentration. 
Therefore, this paper focused on the market structure of the Turkish banking sector over the period 2003-2012. To assess the degree of competition, the study adopted the PanzarRosse approach. Our main findings based on the H-statistics suggested that the banking sector in Turkey is characterized by monopolistic competition. This result may reflect that the Turkish banking industry is dominated by the 10 largest banks, which have approximately an $87 \%$ share of the total assets for the period under this study. Our results are generally consistent with earlier studies that claimed that there was a monopolistic competitive condition.

Finally, to interpret whether there is a change in the market structure of the Turkish banking industry and changes in regulatory rules after the financial crisis of 2000-2001, the results of this study can be compared with the results of the studies applied to data for Turkey before the 2000s (see Aydın (1996), Emek (2005), Kasman (2001), Classens and Leaven (2004), Gelos and Roldos (2004), Günalp and Çelik (2006), Aysan and et. al (2007), Çelik and Kaplan (2010)). Although there have been a growing number of changes in the Turkish banking sector since the 2000s, there has been no remarkable change in the market structure of the Turkish banking sector and it is still characterized by monopolistic competition.

\section{REFERENCES}

- $\quad$ Akyüz, Y. and Boratav, K. (2002), The Making of Turkish Financial Crisis, UNCTAD Discussion Paper, 158

- $\quad$ Al-Muharrami, S. and Matthews, K. (2009). Market power versus efficientstructure in Arab GCC banking. Applied Financial Economics, 19, 1487-1496.

- Alper, C. E and Öniş, Z.(2004), The Turkish Banking System and the IMF in the Age of Capital Account Liberalization, New Perspectives on Turkey, 30, 25-55

- Andries, , A. M. and Capraru, B. (2012a). Competition and efficiency in EU27 banking systems. Baltic Journal of Economics, 12(1), 41-60.

- Andries, A.M. and Capraru, B. (2013). The nexus between competition and efficiency: The European banking industries experience. International Business Review, 22(5), 1046-1059.

- $\quad$ Aydinli, I. (1996) Market Structure of the Turkish Banking System: 1991-1994 (in Turkish), Capital Markets Board Publication, No. 40, Ankara.

- Aysan, A.F., Güneş, A. and Abbasoğlu, O.F.(2007), Concentration, Competition, Efficiency and Profitability of Turkish Banking Sector In the Post-Crisis Period, Boğaziçi University,Department Of Economics, Research Paper, ISS/EC 2007-20, Istanbul. 
- $\quad$ Bain, J. S. (1951). 'Relation of Profit Rate to Industry Concentration', Quarterly Journal of Economics, Vol. 65, pp. 293-324.

- Bikker, J.A. and Groeneveld, J.M. (2000). Competition and Concentration In The EU Banking Industry, Kredit Und Kapital, 33, 62-98.

- Bikker, J.A. and Haaf, K. (2000). Measures of Competition and Concentration in The Banking Industry: A Riview of The Literature. De Nederlandsche Bank Research Series Supervision, No: 27, September.

- $\quad$ Bikker, J. A and Haaf, K. (2002). Competition, Concentration and Their Relationship: An Empirical Analysis of the Banking Industry. Journal of Banking and Finance, 26(11), 2191-2214.

- Casu, B. and Girardone, C. (2009). Testing the relationship between competition and efficiency in banking: A panel data analysis. Economics Letters, 105, 134-137.

- Celik, T. and Kaplan, M. (2010), Türk Bankacılık Sektöründe Etkinlik ve Rekabet :2002-2007,Sosyoekonomi, 2010(2), 100201.

- Cerasi, V. and Daltung, S. (2000). The Optimal Size of a Bank: Costs and Benefits of Diversification. European Economic Review, 44, 1701-1726.

- Claessens, S. and Laeven, L. (2003). What Drives Bank Competition?, Some International Evidence, World Bank Policy Research Working Paper No.3113, World Bank.

- Claessens, S., and Laeven, L. (2004). What Drives Bank Competition?, Some International Evidence, Journal of Money, Credit, and Banking, 36, Part 2, 563584.

- De Bandt, O. and Davis, E.P. (2000). Competition, Contestability and Market Structure in European Banking Sectors On The Eve Of EMU. Journal of Banking and Finance, 24, 1045-1066.

- Delis, M. and Tsionas, E. (2009). The joint estimation of bank-level market power and efficiency. Journal of Banking and Finance, 33(10), 1842-1850.

- Drakos, K. and Konstantinou, P. (2003). Competition and concentration in transition banking: an empirical analysis. EEFS Conference, Heraklion, Crete

- Emek U. (2005). Bankacılık Sisteminde Rekabet ve İstikrar İkileminin Analizi : Türkiye Örneği, Doktora Tezi, Ankara Ünivesitesi Sosyal Bilimler Enstitüsü, Ankara. 
- Gelos, R.G. and Roldos, J., (2004). Consolidation and Market Structure In Emerging Market Banking Systems. Emerging Markets Review 5, 39- 59.

- Günalp, B. and Celik T. (2006). Competition in the Turkish Banking Industry, Applied Economics, 38, 1335-1342.

- Fernandez de Guevara, J., Maudos, J. and Perez, F. (2007). Integration and competition in the European financial markets. Journal of International Money and Finance, 26, 26-45.

- Hughes, J.P. and Mester, L. (1998). Bank capitalization and cost: Evidence of scale economies in risk management and signaling. Review of Economics and Statistics, 80, 314-325.

- Kasman, A. (2001). Competitive Conditions in the Turkish Banking Industry, Ege Akademik Bakıs, 1(2), 72-82.

- Koetter, M., Kolari, J. W. and Spierdijk, L. (2012). Enjoying the quiet life under deregulation? Evidence from adjusted lerner indices for U.S. banks. Review of Economics and Statistics, 94(2), 462-480.

- Lerner, A. (1934). The Concept of Monopoly and the Measurement of Monopoly Power. Review of Economic Studies 1, 157-175.

- Mason, E.S. (1939). Price and production policies of large-scale enterprises. American Economic Review 29 (Supplement), 61-74.

- Murjan, W. and Ruza, C. (2002). The competitive nature of the Arab Middle Eastern Banking Markets. International Advances in Economics, 267-275.

- Nathan, A. and Neave, E.H. (1989). Competition and Contestability in Canada's Financial System: Empirical Results, Canadian Journal of Economics, 22(3), 576594.

- Sayılgan, G and O. Yıldırım (2009), Determinants of Profitability in Turkish Banking Sector: 2002-2007, International Research Journal of Finance and Economics, 28, 207-214.

- Shaffer, S. (1993). A test of competition in Canadian banking. Journal of Money, Credit and Banking 25, 49-61.

- Shaffer, S. (1989). Competition in the US banking industry. Economic Letters, 29, 323-323. 
- Shaffer, S. (2004). Patterns of competition in banking. Journal of Economics and Business, 56, 287-313.

- Shaffer, S. and Disalvo, J. (1994). Conduct in a banking duopoly. Journal of Banking and Finance, 18, 1063-1082.

- Weill, L. (2004). On the relationship between competition and efficiency in the EU banking sectors. Kredit and Kapital, 3, 329-352.

- Yeyati, E.L., and Micco, A., (2003). Concentration and Foreign Penetration in Latin American Banking Sectors: Impact on Competition and Risk (Inter-American Development Bank, Research Department, Working Paper 499).

- Yildirim, H.S. and Philippatos, G.C. (2002). Competition and Contestability in Central and Eastern European Banking Markets, University of Tennessee, Working Paper, September. 